\title{
THE REGULATION OF LIVER TRYPTOPHAN PYRROLASE ACTIVITY DURING THE DEVELOPMENT \\ OF RANA CATESBIANA ${ }^{1}$
}

\author{
MELVIN SPIEGEL AND EVELYN SCLUFER SPIEGEL \\ Department of Biological Sciences, Dartmouth College, Hanover, New Hampshire, and \\ the Marine Biological Laboratory, Woods Hole, Massachusetts
}

Tryptophan pyrrolase (peroxidase-oxidase), the enzyme which catalyzes the formation of formylkynurenine from tryptophan, has been found in the livers of a variety of mammals but not in other tissues (Knox, 1955). Knox and Mehler (1950) have demonstrated that the activity of the enzyme was greatly increased after the injection of tryptophan. Increased liver enzyme levels could, however, be produced by a variety of conditions other than injection of substrate. Such substances as histidine and tyrosine (Knox and Mehler, 1951) and histamine and adrenalin (Knox, 1951) when injected into intact animals produced increased activity of this enzyme. In adrenalectomized animals, liver enzyme activity was increased by injections of adrenocorticotropic hormone (Geschwind and Li, 1953) and the glucocorticoid hormones (Thompson and Mikuta, 1954; Knox and Auerbach, 1955). Knox and Auerbach (1955) concluded that there were probably two types of inducing agents, the substrate and an adrenal hormone.

More recently, Feigelson and Greengard (1961a) have demonstrated that rat liver tryptophan pyrrolase is activated by an iron protoporphyrin, probably hematin, located in the microsomes. Greengard and Feigelson (1961) further demonstrated that, following substrate induction, the enzyme was more fully activated or saturated by its hematin prosthetic group but following cortisone induction, this increased activation did not take place. These results further indicated alternative mechanisms for the initiation of enzyme induction by substrate and the steroid hormones. This conclusion has been substantiated by the recent work of Greengard, Smith and Acs (1963). These authors demonstrated that both inductions were prevented by puromycin, an inhibitor of protein synthesis. Actinomycin D, however, an inhibitor of RNA synthesis, prevented the hydrocortisone induction of tryptophan pyrrolase but did not prevent the induction of this enzyme by its substrate.

Nemeth and Nachmias (1958) and Auerbach and Waisman (1959) have demonstrated that mammalian tryptophan pyrrolase is present only in the adult liver and is absent in fetal liver. Nemeth (1959) measured enzyme activity and its enhancement by tryptophan injection in the liver of the guinea pig, rabbit, and rat in fetal and postnatal stages, including the adult. Injections of tryptophan did not increase enzyme activity in fetal liver, and the response to irijection in all species developed simultaneously with the rapid increase of enzyme activity to adult levels. Constitutive enzyme, therefore, had to be present before induction

${ }^{1}$ Supported by grant G 21810 from the National Science Foundation. 
could take place. Nemeth (1959), as a result of these investigations, concluded that the lack of response of fetal liver to tryptophan injections, as well as to adrenocortical hormones, suggests that substrate induction and adrenocortical secretion are not the mechanisms controlling the increase in enzyme activity during development.

There are two reports in the literature demonstrating substrate induction of tryptophan pyrrolase activity in early development. These are the reports by Stearns and Kostellow (1958) and Kostellow (1961), using dissociated embryonic cells of Rana pipiens. These investigators were not able to detect enzyme activity in intact embryos before hatching but enzyme activity was detected in all cells of embryos dissociated into cell cultures at a stage prior to gastrulation and incubated in L-tryptophan. If L-tryptophan was omitted from the culture medium no activity was detected. As gastrulation proceeded, the ability to be induced by L-tryptophan became progressively restricted to the lightest (in terms of density) endoderm cells.

Kato (1959) attempted to repeat this work on Rana pipiens embryonic cells using Stearns and Kostellow's procedures, Barth and Barth's procedures for the preparation and cultivation of dissociated embryonic cells, and dejellied, but not dissociated, hemisected pre-gastrulae cultivated in Barth and Barth's medium. Kato demonstrated that tryptophan pyrrolase and formylase activity were not induced by substrate in any of the three types of culture.

Furthermore, Stearns and Kostellow (1958) were not able to detect $\beta$ galactosidase activity until some time after hatching. They were, however, able to substrate-induce this enzyme in cells obtained from post-gastrula embryos and regarded this observation as premature activity. Kato, on the other hand, was able to find definite $\beta$-galactosidase activity in stage 12 embryos (Shumway, 1940) but was not able to induce further activity in dissociated cells incubated in substrate. Spiegel and Frankel (1961, and unpublished results) have obtained results similar to those of Kato. Kato has suggested that Stearns and Kostellow's results may have been due to a contamination of their cultures by bacterial cells which would have seriously affected the outcome of this sort of experiment.

Recently Greengard. Smith and Acs (1963) have reported that the adrenalectomy of young rats shortly after birth does not affect the developmental increase of tryptophan pyrrolase activity. They suggest that this result indicates that a substrate-type rather than an adrenocortical secretion-type of regulation is involved in the development of tryptophan pyrrolase activity. They also demonstrated that treatment of young rats with actinomycin D had no effect on the postpartum rise of tryptophan pyrrolase activity. The role, therefore, of substrate-induction in controlling or regulating the synthesis of tryptophan pyrrolase is still open to question.

The results reported by Spiegel and Frankel (1961) with Rana pipiens embryos indicated that tryptophan pyrrolase activity was not detectable through stage 25 (Shumway, 1940) although activity in the amphibian adult liver was comparable to that found in mammalian adult liver, (Spiegel, 1961). It was of interest, therefore, to determine when activity does first appear during amphibian development and to determine, if possible, what the factors are which regulate the enzyme's synthesis and activity. Young tadpoles of Rana pipiens are very 
small and it is necessary in order to assay for tryptophan pyrrolase to either homogenize the entire tadpole or to pool and assay the livers tedionsly dissected from a large number of tadpoles. The former procedure is open to a number of legitimate criticisms. For example, failure to detect activity may reflect either a dilution of activity by the "excess" tissues, or inhibition of liver enzyme activity by the "excess" tissues. The detection of activity may not be solely due to liver enzyme but to other sources. The latter procedure requires a great deal of time and the livers dissected earlier may lose activity during the accumulation of a sufficient number to do an assay. Freezing of livers would not obviate this difficulty, for Spiegel and Spiegel (unpublished results) have demonstrated a loss of activity in adult amphibian livers following this treatment.

For these reasons, therefore, tadpoles of Rana catesbiana, which have considerably larger livers than those of Rana pipiens, were chosen for this study. Tryptophan pyrrolase activity was determined through metamorphosis. During the course of this investigation, further confirmation of the results of Kato and of Spiegel was obtained.

\section{Materials and Methods}

Larval stages and adults of the frog Rana catesbiana were collected in Massachusetts by the Supply Department of the Marine Biological Laboratory from ponds located in the Sippewissett area of Falmouth, Massachusetts. In Hanover, New Hampshire, larval stages were collected by the senior author from Occom Pond. Larvae and adults were maintained in tap water at room temperature. The water was changed three times per week.

For embryonic stages, eggs were obtained by pituitary injection of large adult females and fertilized by the usual method of stripping directly into a suspension of macerated testes in 10\% Holtfreter's solution, pH 7.8 (Holtfreter, 1931). The embryos were then washed three times with sterile $10 \%$ Holtfreter's solution, pH 7.8 , and incubated at $18-22^{\circ} \mathrm{C}$. until the desired stage was attained.

Since there is not any published description of developmental stages of Rana catesbiana, those of Shumway (1940) for the embryonic stages of Rana pipiens and of Taylor and Kollros (1946) for the larval stages of Rana pipiens were applied to corresponding stages of Rana catesbiana. This procedure has been adopted by Brown and Cohen (1958) and others.

From the time of hatching until the cessation of feeding during metamorphosis, tadpoles were fed an excess of either Gaines Dog Meal (General Foods Corporation, Battle Creek, Michigan) or Purina Rabbit Chow (Ralston Purina Co., St. Louis, Missouri) three times per week.

Through stage 14 (Shumway, 1940), the method of Friedberg and Eakin (1949) of cutting embryos into halves and quarters to permit penetration of substrate was used. Accordingly, the jelly and vitelline membrane were removed by dissection with watchmaker forceps. Intact embryos, halves, and quarters were incubated for 12-24 hours in either full-strength Holtfreter's solution or $0.03 M$ L-tryptophan (in full-strength Holtfreter's solution). Cut embryos remained alive as indicated by normal closure of the cut surface in both media. After five washings with the control medium, tryptophan pyrrolase activity was measured in $12.5 \%$ homogenates by the Knox and Auerbach method (1955) as 
modified slightly by Spiegel (1961). For stage 22 embryos 10\% Holtfreter's solution was substituted for the full-strength solution. In larval stages and in adults, livers were dissected out and liver enzyme activity assayed in $12.5 \%$ homogenates as described above. It is important to note that, under these conditions, enzyme activity was directly proportional to concentration of frog liver homogenate. The Knox and Auerbach method is based on the conversion of tryptophan to kynurenine which is the product actually measured during the assay. This conversion, however, is a two-step reaction, tryptophan pyrrolase catalyzing the first step, the conversion of tryptophan to formylkynurenine. The enzyme formylase, which catalyzes the conversion of formylkynurenine, the second step, is found in excess in mammalian liver homogenates and is not rate-limiting (Knox and Mehler, 1950). In all control and experimental frog livers and cut or intact embryos, no reaction products absorbing at $321 \mathrm{~m} \mu$ were detected. This indicated the absence of formylkynurenine, and formylase, therefore, is probably present in excess in frog livers and is not rate-limiting. L-tryptophan, Lhistidine (free-base), hydrocortisone acetate, and L-thyroxine were obtained from Nutritional Biochemicals Corporation, Cleveland, Ohio. Hemin was obtained from Mann Research Laboratories, Inc., New York, N. Y. All injections were given intraperitoneally. All enzyme activities were expressed in terms of $\mu$ moles of kynurenine formed per hour at $38^{\circ}$ C., per gram dry weight of liver (or embryo) \pm standard error of the mean.

\section{REsults}

The results obtained with embryonic stages of Rana catesbiana were comparable to those obtained for Rana pipiens embryos by Spiegel and Frankel (1961). The data of 9 experiments with 3500 embryos per experiment indicated no constitutive tryptophan pyrrolase activity present in either blastula, mid-gastrula, or early neurula stages, using either intact embryos or halves or quarters of embryos. Furthermore, incubation in L-tryptophan failed to induce enzyme activity in these stages. Measurement of tryptophan pyrrolase activity revealed no constitutive enzyme activity in stages 17 and 22 embryos and no indication of activity was noted after tryptophan treatment. In view of the demonstration by Feigelson and Greengard (1961a) that tryptophan pyrrolase is activated by an iron protoporphyrin, probably hematin, the above experiments were repeated with 4 mpmoles of hematin (prepared by dissolving hemin in $0.01 \mathrm{~N} \mathrm{NaOH}$ ) added to the assay mixture. In 5 experiments using 2400 embryos identical results were obtained. There was no constitutive enzyme activity present in the above-mentioned stages and incubation in L-tryptophan failed to induce enzyme activity in these stages.

Table I summarizes the results obtained with larval stages through metamorphosis. It can be seen that enzyme activity in two series of control animals, with and without injection of $0.65 \%$ sodium chloride, steadily decreased from approximately 5 moles kynurenine per hour per gram dry weight at stage I to essentially zero activity by stage XXIII. In other words, before the onset of metamorphosis and sometime after Shumway stage 22, liver tryptophan pyrrolase activity was roughly that found in the adult liver (Spiegel and Spiegel, unpub- 
TABLE I

Liver tryptophan pyrrolase activity of Rana catesbiana tadpoles

\begin{tabular}{|c|c|c|c|}
\hline $\begin{array}{l}\text { Developmental } \\
\text { stage }\end{array}$ & $\begin{array}{l}\text { Number of } \\
\text { animals }\end{array}$ & Treatment & Activity* \\
\hline I & $\begin{array}{r}92 \\
87 \\
100\end{array}$ & $\begin{array}{l}\text { Tryptophan** } \\
0.65 \% \mathrm{NaCl}^{* * *} \\
\text { No injection }\end{array}$ & $\begin{array}{r}28.08 \pm 1.17 \\
4.45 \pm 0.26 \\
5.53 \pm 0.26\end{array}$ \\
\hline XIV & $\begin{array}{r}27 \\
16 \\
8\end{array}$ & $\begin{array}{l}\text { Tryptophan } \\
0.65 \% \mathrm{NaCl} \\
\text { No injection }\end{array}$ & $\begin{array}{r}13.32 \pm 0.70 \\
4.20 \pm 0.17 \\
3.85 \pm 0.39\end{array}$ \\
\hline XVII & $\begin{array}{r}8 \\
8 \\
17\end{array}$ & $\begin{array}{l}\text { Tryptophan } \\
0.65 \% \mathrm{NaCl} \\
\text { No injection }\end{array}$ & $\begin{array}{l}8.87 \pm 0.29 \\
1.46 \pm 0.06 \\
1.32 \pm 0.43\end{array}$ \\
\hline $\mathrm{XX}$ & $\begin{array}{r}8 \\
8 \\
15\end{array}$ & $\begin{array}{l}\text { Tryptophan } \\
0.65 \% \mathrm{NaCl} \\
\text { No injection }\end{array}$ & $\begin{array}{l}1.16 \pm 0.13 \\
1.30 \pm 0.25 \\
0.68 \pm 0.12\end{array}$ \\
\hline XXII & $\begin{array}{r}8 \\
8 \\
13\end{array}$ & $\begin{array}{l}\text { Tryptophan } \\
0.65 \% \mathrm{NaCl} \\
\text { No injection }\end{array}$ & $\begin{array}{l}1.62 \pm 0.31 \\
0.84 \pm 0.01 \\
1.43 \pm 0.46\end{array}$ \\
\hline XXIII & $\begin{array}{r}16 \\
11 \\
7\end{array}$ & $\begin{array}{l}\text { Tryptophan } \\
0.65 \% \mathrm{NaCl} \\
\text { No injection }\end{array}$ & $\begin{array}{l}2.17 \pm 0.04 \\
0.84 \pm 0.27 \\
0.96 \pm 0.43\end{array}$ \\
\hline XXV & $\begin{array}{l}8 \\
8 \\
8\end{array}$ & $\begin{array}{l}\text { Tryptophan } \\
0.65 \% \mathrm{NaCl} \\
\text { No injection }\end{array}$ & $\begin{array}{l}0.74 \pm 0.23 \\
0.98 \pm 0.18 \\
0.94 \pm 0.42\end{array}$ \\
\hline
\end{tabular}

${ }^{*} \mu$ Moles kynurenine formed at $38^{\circ} \mathrm{C}$. per hour per gram of dry weight of liver \pm standard error of the mean.

** $1.0 \mathrm{ml}$. injection of L-tryptophan $(110 \mathrm{mg} . / 10 \mathrm{ml}$. of $0.65 \% \mathrm{NaCl})$. Assayed 5 hours later.

*** $1.0 \mathrm{ml}$. injection. Assayed 5 hours later.

lished results). By the end of metamorphosis, activity in the froglet had virtually disappeared. Table I also demonstrates that substrate-inducibility was correlated with constitutive enzyme activity. Where the constitutive enzyme level was at a high level of activity, e.g., stage I, a 5-6-fold increase in activity was achieved following a single injection of L-tryptophan. At stage XIV, with constitutive enzyme activity at approximately $4 \mu$ moles of kynurenine per hour per gram dry weight, a three-fold increase was noted following L-tryptophan injection. By stage XXV little or no constitutive enzyme activity was detected and no induction was obtained by substrate induction. Experiments with stage XXV embryos, in which 4 m $\mu$ moles of hematin were added to the assay mixture as described above, did not produce any detectable activity.

It was thought that perhaps the loss of inducibility during metamorphosis was correlated with the changes in organs of the digestive system (other than the liver) which take place during metamorphosis (Kaywin, 1936). These changes 
TABLE II

Effect of varying the time after injection of tryptophan on liver tryptophan pyrrolase activity of tadpoles

\begin{tabular}{r|r|r|r|r}
\hline \multirow{2}{*}{$\begin{array}{c}\text { Hours after } \\
\text { injection* }\end{array}$} & \multicolumn{2}{|c|}{ Stage XIV } & \multicolumn{2}{c}{ Stage XXIII } \\
\cline { 2 - 3 } & $\begin{array}{c}\text { Number of } \\
\text { animals }\end{array}$ & Activity** & $\begin{array}{c}\text { Number of } \\
\text { animals }\end{array}$ & Activity \\
\hline 5 & 10 & $14.12 \pm 0.59$ & 11 & $1.76 \pm 0.13$ \\
12 & 12 & $14.89 \pm 0.43$ & 9 & $1.59 \pm 0.28$ \\
17 & 12 & $12.54 \pm 0.61$ & 15 & $1.62 \pm 0.51$ \\
29 & 13 & $13.72 \pm 0.84$ & 8 & $1.23 \pm 0.09$ \\
\hline
\end{tabular}

$* 1.0 \mathrm{ml}$. intraperitoneal injection of L-tryptophan $(110 \mathrm{mg} . / 10 \mathrm{ml}$. of $0.65 \% \mathrm{NaCl})$.

** $\mu$ Moles kynurenine formed at $38^{\circ} \mathrm{C}$. per hour per gram dry weight of liver \pm standard error of the mean.

could have led to a decrease in the rate of uptake of L-tryptophan following an intraperitoneal injection. The assays described in Table I were carried out 5 hours after injection. Accordingly stages XIV and XXIII tadpoles were injected intraperitoneally with L-tryptophan and their livers assayed 5, 12, 17, and 29 hours after injections. More L-tryptophan should be absorbed as the time after injection increased. It can be noted in Table II, however, that no significant change in enzyme activity was noted during the 29-hour period. These results did not completely rule out the possibility of a change in substrate uptake. It is possible that the substrate was metabolized at such a high rate that, even with increased time for uptake, blood and tissue levels in later stages did not reach levels necessary for induction to take place.

TABLE III

Effect of hydrocortisone and L-histidine on tryptophan pyrrolase activity of tadpole livers

\begin{tabular}{|c|c|c|c|}
\hline $\begin{array}{l}\text { Developmental } \\
\text { stage }\end{array}$ & $\begin{array}{l}\text { Number of } \\
\text { animals }\end{array}$ & Treatment & Activity* \\
\hline XIV & $\begin{array}{r}13 \\
8 \\
4 \\
4\end{array}$ & $\begin{array}{l}\text { Hydrocortisone** } \\
\text { Hydrocortisone control*** } \\
\text { L-Histidine } \dagger \\
\text { L-Histidine control†† }\end{array}$ & $\begin{array}{l}3.42 \pm 0.19 \\
4.09 \pm 0.38 \\
5.54 \pm 0.26 \\
4.87 \pm 0.41\end{array}$ \\
\hline XXIII & $\begin{array}{l}4 \\
4 \\
4 \\
4\end{array}$ & $\begin{array}{l}\text { Hydrocortisone } \\
\text { Hydrocortisone control } \\
\text { L-Histidine } \\
\text { L-Histidine control }\end{array}$ & $\begin{array}{l}1.28 \pm 0.46 \\
0.84 \pm 0.27 \\
0.70 \pm 0.42 \\
0.93 \pm 0.56\end{array}$ \\
\hline
\end{tabular}

* $\mu$ Moles kynurenine formed at $38^{\circ} \mathrm{C}$. per hour per gram dry weight of liver \pm standard error of the mean. All animals sacrificed and livers assayed 5 hours after intraperitoneal injection.

** $1 \mathrm{ml}$. injection of hydrocortisone (20 mg. $/ 10 \%$ ethanol in $0.65 \% \mathrm{NaCl}$ ).

*** $1 \mathrm{ml}$. injection of $10 \%$ ethanol in $0.65 \% \mathrm{NaCl}$.

$\dagger 1 \mathrm{ml}$. injection of L-histidine solution prepared by dissolving $38 \mathrm{mg}$. L-histidine in $5 \mathrm{ml}$. of $0.65 \% \mathrm{NaCl}+2 \mathrm{ml}$. of $0.1 \mathrm{~N} \mathrm{NaOH}, \mathrm{pH}$ adjusted to 7.0 by addition of $0.1 \mathrm{~N} \mathrm{HCl}$.

†† $1 \mathrm{ml}$. injection of $5 \mathrm{ml}$. of $0.65 \% \mathrm{NaCl}+2 \mathrm{ml}$. of $0.1 \mathrm{~N} \mathrm{NaOH}$, pH adjusted to 7.0 by addition of $0.1 \mathrm{~N} \mathrm{HCl}$. 
TABLE IV

Effect of L-thyroxine treatment on tryptophan pyrrolase activity of livers of stage I tadpoles

\begin{tabular}{c|c|c|c|c}
\hline \multirow{2}{*}{ Treatment } & \multicolumn{2}{|c|}{$\begin{array}{c}\text { Tadpoles cultured in } 3 \times 10^{-8} M \\
\text { L-thyroxine for } 36 \text { hours }\end{array}$} & \multicolumn{2}{c}{$\begin{array}{c}\text { Tadpoles cultured in tap water } \\
\text { for } 36 \text { hours }\end{array}$} \\
\cline { 2 - 3 } & $\begin{array}{c}\text { Number ot } \\
\text { animals }\end{array}$ & Activity* & $\begin{array}{c}\text { Number of } \\
\text { animals }\end{array}$ & Activity \\
\hline Tryptophan** & 49 & 18.58 & 50 & 36.34 \\
$0.65 \% \mathrm{NaCl}^{* * *}$ & 50 & 4.18 & 50 & 6.89 \\
\hline
\end{tabular}

${ }^{*} \mu$ Moles kynurenine formed at $38^{\circ} \mathrm{C}$. per hour per gram dry weight of liver.

** $0.1 \mathrm{ml}$. intraperitoneal injection of L-tryptophan $(110 \mathrm{mg} . / 10 \mathrm{ml} .0 .65 \% \mathrm{NaCl})$ and liver assayed 24 hours later.

*** $0.1 \mathrm{ml}$. intraperitoneal injection and liver assayed 24 hours later.

In an effort to learn whether this loss of activity during metamorphosis was due to the progressive loss of ability of the adrenal cortex to synthesize steroids, tadpoles were injected with hydrocortisone and L-histidine. These compounds induce tryptophan pyrrolase activity in adult mammalian livers but not in adult Rana pipiens livers (Spiegel, 1961). Table III shows that hydrocortisone and L-histidine had no significant effect on the tryptophan pyrrolase activity of stage XIV and XXIII embryos.

Tables IV and $\mathrm{V}$ demonstrate that culture of tadpoles in L-thyroxine solutions leads to a $30-50 \%$ loss in constitutive enzyme activity within $24-36$ hours. They further demonstrate that substrate-inducibility in the tadpole is correlated with constitutive enzyme activity. In animals injected with L-tryptophan and cultured in L-thyroxine, enzyme activity is usually less than half of that in animals injected with substrate and cultured in tap water. The degree of inducibility in

\section{TABLE V}

Effect of L-thyroxine treatment on inducibility, by tryptophan*, of tryptophan pyrrolase of livers of stage XIV tadpoles

\begin{tabular}{|c|c|c|c|c|}
\hline \multirow{2}{*}{$\begin{array}{l}\text { Number of days } \\
\text { cultured in solution }\end{array}$} & \multicolumn{2}{|c|}{ Tadpoles cultured in thyroxine ${ }^{* *}$} & \multicolumn{2}{|c|}{ Tadpoles cultured in tap water } \\
\hline & $\begin{array}{l}\text { Number of } \\
\text { animals }\end{array}$ & Activity*** & $\begin{array}{l}\text { Number of } \\
\text { animals }\end{array}$ & Activity \\
\hline 1 & 4 & 7.20 & 2 & 14.18 \\
\hline 2 & 4 & 2.63 & 2 & 18.39 \\
\hline 4 & 4 & 8.24 & 2 & 17.39 \\
\hline 6 & 4 & 3.02 & 2 & 14.28 \\
\hline 8 & 4 & 7.79 & 2 & 16.69 \\
\hline
\end{tabular}

* Each tadpole was injected intraperitoneally with $1 \mathrm{ml}$. of L-tryptophan $(110 \mathrm{mg} . / 10 \mathrm{ml}$. $0.65 \% \mathrm{NaCl}$ ) and its liver assayed 5 hours later.

** Tadpoles were cultured in $3 \times 10^{-8} M$ L-thyroxine in tap water $(1$ tadpole $/ 200 \mathrm{ml}$. solution) and solution was changed at 24 -hour intervals. Controls were treated in same manner with tap water substituted for thyroxine.

*** $\mu$ Moles kynurenine formed at $38^{\circ} \mathrm{C}$. per hour per gram dry weight of liver. 
L-thyroxine is considerably reduced and the L-tryptophan injection could not counteract the inhibitory effect of L-thyroxine. This result further supports the repeated observation that the degree of substrate-induction of this enzyme, in the frog, is correlated with the amount of constitutive enzyme in the liver.

In an effort to learn whether the loss of enzyme activity during metamorphosis was due either to a loss of an activator or conversely, to the appearance of an inhibitor, a series of experiments were carried out in which equal volumes of liver homogenates of L-tryptophan-injected stage XIV and XXIII larvae were mixed together. The mixed homogenate, as well as the separate homogenates, were then assayed by the usual procedure. L-tryptophan-injected tadpoles were used to increase the level of activity of the enzyme in stage XIV and, if possible, in stage XXIII so that any marked change in activity of the mixed homogenate would be more reliable and within the sensitivity of the assay method. The results of this experiment are summarized in Table VI. It can be noted that the

TABLE VI

Effect on tryptophan pyrrolase activity of mixing stage XIV and stage XXIII homogenates of livers from L-tryptophan-injected* tadpoles

\begin{tabular}{lcr}
\hline \hline Type of homogenate** & Number of experiments & Activity*** \\
\hline Stage XIV & 10 & $14.78 \pm 0.49$ \\
Stage XXIII & 10 & $0.71 \pm 0.03$ \\
Stage XIV + XXIII ${ }^{* * * *}$ & 10 & $3.25 \pm 0.41$
\end{tabular}

* Injected intraperitoneally with $1.0 \mathrm{ml}$. of L-tryptophan $(110 \mathrm{mg} . / 10 \mathrm{ml} .0 .65 \% \mathrm{NaCl})$ and livers assayed 5 hours later.

**.Prepared and assayed by the Knox and Auerbach procedure.

$* * * \mu$ Moles kynurenine formed at $38^{\circ} \mathrm{C}$. per hour per gram dry weight of liver \pm standard error of the mean.

**** Equal volumes.

activity of the stage XIV homogenates was an average of $14.78 \mu$ moles for 10 experiments and that of stage XXIII homogenates $0.71 \mu$ mole for 10 experiments. The expected value for the mixed homogenate (the average activity of the two separate homogenates) was 7.75 mmoles. A series of additional experiments with varying proportions of the two homogenates led to the same result; the observed enzyme activity was always less than the expected value. These results suggest the presence of an inhibitor of tryptophan pyrrolase activity in stage XXIII liver homogenates.

\section{Discussion}

The observation that liver tryptophan pyrrolase activity appears sometime after stage 22 in Rana catesbiana embryos, only to be followed by its virtual disappearance by the end of metamorphosis and reappearance in the adult, is of serious consequence to the developmental biologist who chooses to study the ontogeny of enzymes and structural proteins. Tyler (1957) and Spiegel (1960) have considered the possibility that proteins, during development, may change in their solubility and/or intracellular location. If these events occurred, it would 
lead to difficult and often misleading interpretations of data of analyses obtained using a single method of extraction. Indeed, Solomon (1959) has elegantly demonstrated changes in solubility for the enzyme, glutamic dehydrogenase, in the developing chick embryo. The finding that an enzyme confined, as far as is known, to a single organ can virtually disappear and then reappear later in development is, as far as the authors are aware, without parallel.

The results obtained in this investigation do not, of course, rule out the possibility that the larval enzyme is a quite different protein(s) from that of the adult as, for example, is the case for fetal and adult hemoglobin (Shelton and Schroeder, 1960) or for the isozymes of lactic dehydrogenase in developing mouse muscle (Markert and Ursprung, 1962). Further investigations of these possibilities are being carried out in our laboratory at the present time.

Regardless of the outcome, the results obtained with tryptophan pyrrolase, the hemoglobins, lactic dehydrogenases, and other proteins amply illustrate the complexity of carrying out studies on the synthesis of proteins in development. In particular, the earlier approach to the problem of ontogenetic changes in proteins, in which organ and tissue extracts containing numerous soluble macromolecules of unknown function are analyzed by a variety of biochemical and immunological techniques, is difficult and perhaps impossible to interpret with meaning. The use of numerous proteins of unknown function(s) for studies in development decreases the probability of interpreting the molecular events involved in the developmental process.

The finding that tryptophan pyrrolase cannot be precociously induced in the bullfrog embryo by its substrate in the absence of demonstrable amounts of constitutive enzyme activity is in agreement with the earlier observation by Spiegel and Frankel (1961) for Rana pipiens embryos and by Nemeth (1959) for fetal livers. The demonstration of a positive correlation between constitutive enzyme activity and degree of substrate-inducibility serves as additional confirmation of this observation. It should be made apparent, however, that failure to precociously induce enzyme activity by injection of, or culture in, L-tryptophan does not rule out the possibility of a substrate-type of induction occurring intracellularly during development. Secondly, the possibility exists that, under the conditions employed for culture of early embryos, the cells were impermeable to substrate. Finally, it is possible that the failure to induce enzyme activity by substrate in larval stages may be due to a failure of the gut wall and lining of the body cavity to absorb appreciable amounts of L-tryptophan. The fact that tadpoles stop eating during metamorphosis would appear to reinforce this explanation. Enzyme activity would presumably decrease in the absence of food (and presumably of L-tryptophan). An attempt to explore this possibility through the use of perfused livers by the techniques of Goldstein, Stella and Knox (1962) has not been successful thus far. All attempts in our laboratory (unpublished results) of perfusing tadpole and adult frog livers with and without L-tryptophan solutions have led to a rapid loss of constitutive enzyme activity and a failure by substrate to induce or even maintain activity. The demonstration of the presence of an inhibitor in stage XXIII tadpoles indicates that, at least for later stages, a mechanism of inhibition operates rather than the absence of substrate in regulating tryptophan pyrrolase activity. 
The failure of either hydrocortisone or of L-histidine to induce liver tryptophan activity in stages XIV and XXIII is not unexpected. Spiegel (1961) has demonstrated that hydrocortisone, L-histidine, cortisone, and adrenocorticotropic hormone (ACTH) fail to induce enzyme activity in the livers of adult Rana pipiens. This finding is in direct contrast to the mammalian data in which enzyme activity can be induced in adult livers by these substances. It should be pointed out, however, that Nemeth (1959) failed to obtain induction in mammalian fetal livers (in which constitutive enzyme activity is lacking) by either substrate or adrenocortical hormones. The failure of adrenal steroids to induce activity in the amphibian is indeed puzzling. Schotté and Chamberlain (1955) and Schotté and Bierman (1956) have furnished evidence for the existence of a pituitary-adrenal axis for regenerative processes in the urodele. Regenerative capacities of the hypophysectomized newt were restored when injected with either ACTH or cortisone. Furthermore, Schotté and Wilber (1958) have furnished additional evidence indicating the existence of this synergism in Rana clamitans and Rana pipiens. Levinsky and Sawyer (1952) have demonstrated that ACTH can partially counteract the decrease in water-balance response to pitocin following hypophysectomy of adult male Rana pipiens. The suggestion by Spiegel (1961) that the amphibian adrenal cortical hormones are different from those of the mammal remains as an explanation of the failure of the mammalian hormones to induce enzyme activity. Secondly, the alternative pathway of enzyme induction by steroid hormones, as indicated by the work of Knox and Auerbach (1955) and Greengard, Smith and Acs (1963), may not be present in the amphibian. An analysis of additional steroid-inducible systems in the frog is of importance in this respect.

The observation that a decrease in the constitutive and inducible activity of liver tryptophan pyrrolase occurs following culture of tadpoles in L-thyroxine solution is similar to the decrease in changes in succinoxidase activity of the bullfrog following thyroxine treatment (Paik and Cohen, 1960) and duplicates the naturally occurring event during metamorphosis. While it is attractive to think of thyroxine as the inhibitory agent, little information is available to shed light on this hypothesis. When thyroxine has been added to the assay mixture in varying amounts, no in vitro effect has been observed in either larval or adult liver homogenates (Spiegel and Spiegel, umpublished results).

Of extreme importance is the finding that stage XXIII tadpole livers contain an inhibitor of tryptophan pyrrolase activity. The data, however, can not be interpreted in terms of apoprotein concentrations. At least two possibilities exist. Stage XXIII tadpole livers may contain appreciable amounts of apoprotein which is inhibited or, secondly, there may be no significant amounts of apoprotein present. The recent isolation of the apoprotein of mammalian tryptophan pyrrolase by Feigelson and Greengard (1961b), if adaptable to the frog liver, will permit the evaluation of these possibilities. The data do not permit the identification of the inhibitor substance as a repressor of genetic activity (Jacob and Monod, 1961). Their hypothesis is so attractive, however, to the developmental biologist, that further experiments must consider it. 


\section{SumMARY}

1. Liver tryptophan pyrrolase activity was studied in embryonic, larval, and adult Rana catesbiana. Constitutive enzyme activity appeared after Shumway stage 22, disappeared during metamorphosis, and was again detected in appreciable amounts in the adult.

2. Substrate inducibility was positively correlated with constitutive enzyme activity. In no case was enzyme activity induced by substrate in the absence of detectable constitutive enzyme activity.

3. Culture of tadpoles in thyroxine solutions led to the suppression of enzyme activity.

4. L-histidine and hydrocortisone had no effect on liver tryptophan pyrrolase activity.

5. The appearance, during metamorphosis, of tryptophan pyrrolase activity was described.

6. The implications of these findings were discussed in terms of further experiments on the ontogeny of macromolecules.

\section{LITERATURE CITED}

Auerbach, V. H., and H. A. Waisman, 1959. Tryptophan peroxidase-oxidase, histidase, and transaminase activity in the liver of the developing rat. J. Biol. Chem., 234: 304-306.

Brown, G. W., JR., And P. P. Cohen, 1958. Biosynthesis of urea in metamorphosing tadpoles. In: A Symposium on the Chemical Basis of Development, edited by W. D. McElroy and B. Glass, The Johns Hopkins Press, Baltimore, Md., pages 495-513.

Feigelson, P., and O. Greengard, 1961a. A microsomal iron-porphyrin activator of rat liver tryptophan pyrrolase. J. Biol. Chem., 236: 153-157.

Feigelson, P., and O. Greengard, 1961b. The isolation of the apoprotein of the heme enzyme tryptophan pyrrolase. Biochim. Biophys. Acta, 50: 200-202.

Friedberg, F., and R. M. Eakin, 1949. Studies in protein metabolism of the amphibian embryo. I. Uptake of radioactive glycine. J. Exp. Zool., 110: 33-46.

Geschwind, I. I., ANd C. H. LI, 1953. Influence of hypophysectomy and of adrenocorticotropic hormone on a mammalian adaptive enzyme system. Nature, 172: 732-733.

Goldstein, L., E. J. Stella and W. E. Knox, 1962. The effect of hydrocortisone on tyrosine- $\alpha-$ ketoglutarate transaminase and tryptophan pyrrolase activities in the isolated, perfused rat liver. J. Biol. Chem., 237: 1723-1726.

Greengard, O., and P. Feigelson, 1961. A difference between the modes of action of substrate and hormonal inducers of rat liver tryptophan pyrrolase. Nature, 190: 446-447.

Greengard, O., M. A. Smith and G. Acs, 1963. Relation of cortisone and synthesis of ribonucleic acid to induced and developmental enzyme formation. J. Biol. Chem., 238: $1548-1551$.

Holtfreter, J., 1931. Über die Aufzuch isolierter Teile des Amphibienkeimes. II. Züchtung von Keimen und Keimteilen in Salzlösung. Arch.f. Entw., 124: 404-466.

JAсов, F., And J. Monod, 1961. Genetic regulatory mechanisms in the synthesis of proteins. J. Mol. Biol., 3: 318-356.

Kaywin, L., 1936. A cytological study of the digestive system of anuran larvae during accelerated metamorphosis. Anat. Rec., 64: 413-437.

Kato, Y., 1959. A study of enzyme induction in dissociated embryonic cells of Rana pipiens embryos. In: Carnegie Institution of Washington Year Book 59, The Lord Baltimore Press, Inc., Baltimore, Md., pages 386-389.

Knox, W. E., 1951. Two mechanisms which increase in vivo the liver tryptophan peroxidase activity: specific enzyme adaptation and stimulation of the pituitary adrenal system. Brit. J. Exp. Pathol., 32: 462-469. 
Knox, W. E., 1955. Tryptophan oxidation. In: Methods in Enzymology, edited by S. P. Colowick and N. O. Kaplan, Academic Press, Inc., Publishers, New York, N. Y., pages 242-253.

Knox, W. E., And V. H. Auerbach, 1955. The hormonal control of tryptophan peroxidase in the rat. J. Biol. Chem., $214: 307-313$.

Knox, W. E., And A. H. Mehler, 1950. The conversion of tryptophan to kynurenine in liver. I. The coupled tryptophan peroxidase system forming formylkynurenine. J. Biol. Chem., 187: 419-438.

Knox, W. E., And A. H. Menler, 1951. The adaptive increase of the tryptophan peroxidaseoxidase system of liver. Science, 113: 237-238.

Kostellow, A. B., 1961. Induced enzyme synthesis in cell cultures of embryonic $R$. pipiens. Fed. Proc., 20: 222.

Levinsky, N. G., and W. H. Sawyer, 1952. Influence of the adenohypophysis on the frog water-balance response. Endocrinol., 51: 110-116.

Markert, C. L., and H. Ursprung, 1962. The ontogeny of isozyme patterns of lactate dehydrogenase in the mouse. Dev. Biol., $5:$ 363-381.

Nemeth, A. M., 1959. Mechanisms controlling changes in tryptophan peroxidase activity in developing mammalian liver. J. Biol. Chem., 234: 2921-2924.

Nemeth, A. M., and V. T. Nachmias, 1958. Changes in tryptophan peroxidase activity in developing liver. Science, 128: 1085-1086.

Paik, W. K., And P. P. Cohen, 1960. Biochemical studies on amphibian metamorphosis. I. The effect of thyroxine on protein synthesis in the tadpole. J. Gen. Physiol., 43: 683696.

Schotté, O. E., and R. Bierman, 1956. Effects of cortisone and allied adrenal steroids upon regeneration in hypophysectomized Triturus viridescens. Rev. Suisse Zool., 63: 353-375.

Schotté, O. E., and J. Chamberlain, 1955. Effect of ACTH upon limb regeneration in normal and in hypophysectomized Triturus viridescens. Rev. Suisse Zool., 62: 253-279.

Schotté, O. E., AND J. F. Wilber, 1958. Effects of adrenal transplants upon forelimb regeneration in normal and in hypophysectomized adult frogs. J. Embryol. Exp. Morphol., $1: 24-42$.

Shelton, J. R., And W. A. Schroeder, 1960. Further N-terminal sequences in human hemoglobins A, S, and F by Edman's phenylthiohydantoin method. J. Amer. Chem. Soc., 82: $3342-3345$.

Shumway, W., 1940. Stages in the normal development of Rana pipiens. I. External form. Anat. Rec., 78: 139-147.

Solomon, J. B., 1959. Changes in the distribution of glutamic, lactic and malic dehydrogenases in liver cell fractions during the development of the chick embryo. Dev. Biol., 1: 182-198.

Spiegel, M., 1960. Protein changes in development. Biol. Bull., 118: 451-462.

SPIEGEL, M., 1961. Tryptophan pyrrolase in the liver of adult Rana pipiens. Biol. Bull., 121: $547-553$.

Spiegel, M., and D. L. Frankel, 1961. Role of enzyme induction in embryonic development. Science, 133: 275 .

Stearns, R. N., and A. B. Kostellow, 1958. Enzyme induction in dissociated embryonic cells. In: A Symposium on the Chemical Basis of Development, edited by W. D. McElroy and B. Glass, The Johns Hopkins Press, Baltimore, Md., pages 448-453.

Taylor, A. C., and J. J. Kollros, 1946. Stages in the normal development of Rana pipiens larvae. Anat. Rec., 94: 7-23.

Thompson, J. F., And E. T. Mikuta, 1954. Effect of total body X-irradiation on the tryptophan peroxidase activity of rat liver. Proc. Soc. Exp. Biol. Med.. 85: 29-32.

Tyler, A., 1957. Immunological studies of early development. In: The Beginnings of Embryonic Development. Amer. Assoc. Adv. of Sci., Washington, D. C., pages 341-382. 


\section{$2 \mathrm{BHL}$ Biodiversity Heritage Library}

Spiegel, Melvin and Spiegel, Evelyn Sclufer. 1964. "THE REGULATION OF LIVER TRYPTOPHAN PYRROLASE ACTIVITY DURING THE DEVELOPMENT OF RANA CATESBIANA." The Biological bulletin 126, 307-318.

https://doi.org/10.2307/1539529.

View This Item Online: https://www.biodiversitylibrary.org/item/17163

DOI: https://doi.org/10.2307/1539529

Permalink: https://www.biodiversitylibrary.org/partpdf/19626

\section{Holding Institution}

MBLWHOI Library

\section{Sponsored by}

MBLWHOI Library

\section{Copyright \& Reuse}

Copyright Status: In copyright. Digitized with the permission of the rights holder.

License: http://creativecommons.org/licenses/by-nc-sa/3.0/

Rights: https://biodiversitylibrary.org/permissions

This document was created from content at the Biodiversity Heritage Library, the world's largest open access digital library for biodiversity literature and archives. Visit BHL at https://www.biodiversitylibrary.org. 